\title{
PENGGUNAAN METODE MIND MAPPING DALAM MENINGKATKAN HASIL BELAJAR SISWA
}

\author{
NINA GANTINA KUSTIAN
}

SMPN 1 Bojonggenteng Sukabumi Jawa Barat

Email : ninakustiang.28@gmail.com

\begin{abstract}
ABSTRAK
Penelitian ini dilakukan bertujuan untuk menganalisis penggunaan metode mind mapping dalam meningkatkan hasil belajar. Penelitian ini masuk dalam penelitian kualitatif, kategori penelitian kepustakaan (library research). Penelitian kepustakaan adalah suatu penelitian menggunakan kajian teoritis yang digunakan dalam mengumpulkan informasi dan data dengan bantuan berbagai macam informasi yang ada di perpustakaan seperti buku, jurnal, berita dll. Data-data tersebut dikumpulkan dengan teknik dokumentasi, yaitu dengan jalan membaca (text reading), mengkaji, mempelajari, dan mencatat literatur yang ada kaitannya dengan pembelajaran. Penggunaan maind mapping dalam meningkatkan hasil belajar tentu dipilih guru sebagai salah satu alternatif. Menurut Dimyati dan Mudjiono (2009 : 200) hasil belajar merupakan tingkat keberhasilan yang diperoleh oleh siswa setelah mengikuti suatu kegiatan pembelajaran yang ditandai dengan nilai. Hasil belajarbukan suatu penguasaan hasil latihan melainkan pengubahan kelakuan (Hamalik, 2008: 27). Berdasarkan hasil analisis data dan pembahasan, maka kesimpulan yang dapat diambil dari penelitian ini adalah penerapan metode mind mapping dapat meningkatkan hasil belajar siswa.
\end{abstract}

Kata Kunci: Mind Mapping, dan Hasil Belajar

\section{PENDAHULUAN}

Metode merupakan sesuatu yang penting dan diperlukan serta diperhatikan dalam proses belajar mengajar karena metode merupakan salah satu alat untuk mencapai tujuan. Dengan memanfaatkan metode secara akurat, sehingga guru akan mampu mencapai tujuan pembelajaran

Pemilihan dan penentuan metode dalam pembelajaran harus memiliki:

(1) Nilai strategi dan metode didalam proses pembelajaran sering terjadi interaksi edukatif antara anak didik dan guru. Pengalaman membuktikan bahwa kegagalan pembelajaran salah satunya disebabkan oleh pemilikan metode yang kurang tepat. Oleh karena itu metode adalah salah satu cara yang memilliki nilai strategis dalam kegiatan belajar mengajar. Nilai strategis dari metode adalah dapat mempengaruhi jalannya pembelajaran

(2) Efektivitas penggunaan metode Penggunaan metode yang tidak sesuai dengan tujuan pembelajaran akan menjadikan kendala dalam mencapai tujuan yang dirumuskan, karena itu, efektivitas penggunaan metode dapat terjadi bila ada kesesuain metode dengan semua komponen pembelajaran yang telah diprogramkan

(3) Pentingnya pemilihan dan penentuan metode Titik sentral yang harus dicapai oleh setiap pembelajaran adalah tercapainya tujuan pembelajaran. Apapun yang termasuk perangkat program pembelajaran dituntut secara mutlak untuk menunjang tercapainya tujaun guru sebagai salah satu sumber belajar berkewajiban menyediakan lingkungan belajar yang kreatif bagi kegiatan belajar anak didk dikelas. Djamarah (2002:85-93),

Mind map adalah salah suatu model pembelajaran yang memanfaatkan instrumen yang dapat membantu memetakan isi atau materi sehingga lebih mudah dipelajari dan dianalisis. Sebagai suatu instrumen, mind map dapat dikategorikan sebagai cognitive organizers yang bekerja sebagai stimulator agar kognisi manusia dapat bekerja lebih efektif dan efisien (Chen dan Hung, 2014: 262). Mind map membantu individu agar mampu menempatkan informasi ke dalam suatu sistem kognisi dan mengeluarkannya kembali(recall) untuk dimanfaatkan sebagai dasar pengetahuan. Sebagai suatu alat, mind map dapat 
diandalkan sebagai tehnik mencatat yang kreatif dan efektif membantu individu untuk memetakan pikirannya (Buzan, 2013: 4).

Dalam pengertian lain, maind map adalah salah satu cara mengorganisasikan dan menyajikan konsep, ide atau informasi dalam bentuk diagram radial-hierarki non-linear yang melibatkan bentuk pencatatan dengan struktur dua dimensi sehingga dapat mengakomodasi bentuk keseluruhan topik, kepentingan serta hubungan relatif masing-masing komponen dan mekanisme penghubungnya. Dibandingkan dengan pencatatan biasa, mind map membantu mengaktifkan kognisi, fokus dan menunjukkan hubungan antar bagian-bagian terpisah, menggambarkan keseluruhan secara jelas,memerinci materi dan mengalihkan informasi dari ingatan jangka pendek ke ingatan jangka panjang (Putra, 2008: 257).

Swardarma (2013) menyatakan bahwa: "Mind Map merupakan teknik pemanfaatan keseluruhan otak dengan menggunakan citra visual dan prasarana grafis lainnya untuk membentuk kesan". Sedangkan Olivia (2013) menyatakan bahwa: "Mind Map merupakan salah satu cara menyeimbangkan kedua belahan otak kiri dan otak kanan". Sedangkan Windura (2013:) mendefinisikan Mind Map sebagai berikut:

a) Sistem belajar dan berpikir yang menggunakan kedua belah otak,

b) Sistem belajar dan berpikir yang menggunakan otak sesuai dengan cara kerja ilmiah,

c) Sistem belajar dan berpikir yang mengeluarkan seluruh potensi dan kapasitas otak menggunannya yang masih tersembunyi,

d) Sistem belajar dan berpikir yang mencerminkan apa yang terjadi secara internal di dalam otak kita saat belajar dan berfikir,

e) Sistem belajar dan berpikir yang menceriminkan secara visual apa yang terjadi pada otak anda saat belajar dan berpikir.

Pada dasarnya Mind Map dihasilkan dari perpaduan antara pola berfikir lurus dan pola berfikir memancar, kegunaan Mind Map dalam rangka mengembangkan kemampuan motorik halus anak, mengembangkan kemampuan motorik halus anak banyak yang terfokus kepada hasil akhir, yaitu agar anak cepat menulis. Padahal yang lebih penting adalah proses perangsangan jalur-jalur syaraf otak anak sendiri. Apabila kita mampu memberikan rangsangan yang tepat maka otak anak akan berkembang pesat dan mampu berfikir lebih cepat.

Metode mind mapping mempunyai kelebihan-kelebihan yang berdampak positif bagi pembelajaran, seperti yang dikemukakan Warseno 2011:83 (dalam Agustina, 2013: 9) Beberapa kelebihan menggunakan Mind Mapping ini yaitu :

a) Dapat melihat gambaran secara menyeluruh dengan jelas.

b) Dapat melihat detailnya tanpa kehilangan benang merah antar topik.

c) Terdapat pengelompokan informasi.

d) Menarik perhatian mata dan tidak membosankan.

e) Memudahkan kita berkonsentrasi.

f) Proses pembuatannya menyenangkan karena melibatkan gambar, warna, dan lain-lain, serta

g) Mudah mengingatnya karena ada penanda visualnya.

Selebihnya Warseno 2011:83 (dalam Agustina, 2013: 9) juga mengungkapkan bahwa penggunaan metode mind mapping tidak terlepas dari adanya kekurangan. Kekurangan tersebut diantaranya :

a) Hanya peserta didik yang aktif yang terlibat.

b) Tidak sepenuhnya murid belajar.

c) Mind map peserta didik bervariasi sehingga guru akan kewalahan memeriksa mind map peserta didik.

Penggunaan maind mapping dalam meningkatkan hasil belajar tentu dipilih guru sebagai saah satu alternatif. Menurut Dimyati dan Mudjiono (2009:200) hasil belajar merupakan tingkat keberhasilan yang diperoleh oleh siswa setelah mengikuti suatu 
kegiatan pembelajaran yang ditandai dengan nilai. Hasil belajar bukan suatu penguasaan hasil latihan melainkan pengubahan kelakuan (Hamalik, 2008: 27).

Dengan banyaknya penelitian yang mengambil topik metode mind mapping yang berhubungan dengan hasil belajar siswa baik di tingkat SD/MI, SMP/MTs. maupun SMA/SMK/MAN maka penulis berinsisiatif untuk melakukan penelitian literatur dengan mengambil judul: "Penggunaan Metode Mind Mapping dalam Meningkatkan Hasil Belajar Siswa" (Suatu Tinjauan Literatur). Adapun rumusan masalah yang timbul berdasarkan latar belakang tersebut adalah "Apakah penggunaan metode mind mapping dapat meningkatkan hasil belajar?", sedangkan tujuan penelitian adalah untuk mengetahui pengggunakan metode Mind Mapping dalam kaitannya dengan hasil belajar siswa

\section{METODE PENELITIAN}

Jenis penelitian ini adalah penelitan kepustakaan (library research), yaitu serangkaian penelitian yang berkenaan dengan metode pengumpulan data pustaka, atau penelitian yang obyek penelitiannya digali melalui beragam informasi kepustakaan (buku, ensiklopedi, jurnal ilmiah, koran, majalah, dan dokumen). Penelitian kepustakaan atau kajian literatur (literature review, literature research) merupakan penelitian yang mengkaji atau meninjau secara kritis pengetahuan, gagasan, atau temuan yang terdapat di dalam tubuh literatur berorientasi akademik (academic-oriented literature), serta merumuskan kontribusi teoritis dan metodologisnya untuk topik tertentu. Fokus penelitian kepustakaan adalah menemukan berbagai teori, hukum, dalil, prinsip, atau gagasan yang digunakan untuk menganalisis dan memecahkan pertanyaan penelitian yang dirumuskan.

Adapun sifat dari penelitian ini adalah analisis deskriptif, yakni penguraian secara teratur data yang telah diperoleh, kemudian diberikan pemahaman dan penjelasan agar dapat dipahami dengan baik oleh pembaca. Nana Syaodih. (2009: 52)

Data yang digunakan dalam penelitian ini adalah data sekunder. Data sekunder merupakan data yang diperoleh bukan dari pengamatan langsung. Akan tetapi data tersebut diperoleh dari hasil penelitian yang telah dilakukan oleh peneliti-peneliti sebelumnya. Sumber data sekunder yang dimaksud berupa buku dan laporan ilmiah primer atau asli yang terdapat di dalam artikel atau jurnal (tercetak dan/atau non-cetak) berkenaan dengan metode mind mapping dan hasil belajar yang dialami siswa

\section{HASIL DAN PEMBAHASAN}

Mind mapping merupakan metode pembelajaran yang dirancang untuk mengembangkan pengetahuan siswa dengan kegiatan kreatif menyusun ide-ide pokok dari sebuah konsep menjadi sebuah peta pikiran yang mudah dipahami oleh siswa.

Sedangkan hasil belajar merupakan salah satu indikator yang dapat digunakan untuk mengukur keberhasilan belajar seseorang . Menurut Maisaroh dan Rostrieningsih. 2010: ada banyak faktor yang mempengaruhi pencapaian nilai hasil belajar siswa, baik berasal dalam diri siswa (internal) maupun dari lingkungan luar (eksternal). Faktor internal terkait dengan disiplin, respon dan motivasi siswa, sedangkan faktor eksternal berasal dari lingkungan belajar, kreatifitas pemilihan media belajar oleh guru serta metode pembelajaran.

Pemilihan metode pembelajaran yang tepat akan membawa suasana belajar yang menyenangkan dan memungkinkan siswa untuk mengembangkan kreatifitas. Suasana belajar yang menyenangkan akan membawa dampak pada motivasi belajar dan disiplin yang meningkat. Motivasi yang tinggi menjadi salah satu faktor penentu keberhasilan siswa dalam mencapai hasil belajar yang terbaik. Dalam kegiatan belajar mengajar (KBM), seorang guru memiliki peranan yang sangat penting. Menurut Sudarman (2009), kehadiran guru dalam proses pembelajaran masih tetap memegang peranan penting. Oleh karena itu guru perlu memiliki keterampilan dalam memilih metode yang tepat ketika menyampaikan suatu materi 
kepada peserta didiknya agar menjadi lebih menarik, tidak mengalami kebosanan dan dapat menerima materi tersebut dengan mudah, yang akan menunjang prestasi belajarnya.

Penelitian ini didasarkan pada studi dokumen yang diambil dari hasil-hasil penelitian yang sebelumnya sudah diterapkan dan teruji. Atas dasar artikel jurnal-jurnal dan buku dari adanya hasil pencarian ataupun penelusuran yang sudah dipilih, dipilah dan ditelusuri menggunakan media Google Scholar yang sudah terseleksi. Sebagai salah satu metode pembelajaran Mind mapping sangat efektif dalam meningkatkan prestasi belajar siswa. Hal ini terbukti dari beberapa literatur yang telah peneiti rangkum ssebagai berikut:

Tabel 1. Daftar Rangkuman Literatur

\begin{tabular}{|c|c|c|c|c|}
\hline No & Penulis & $\begin{array}{c}\text { Judul } \\
\text { Penelitian }\end{array}$ & Tahun & Hasil Penelitian \\
\hline 1. & $\begin{array}{l}\text { Nita Mei } \\
\text { Ekawati, dan } \\
\text { Diana } \\
\text { Kusumaningrum }\end{array}$ & $\begin{array}{l}\text { Pengaruh } \\
\text { Penerapan } \\
\text { Metode } \\
\text { Pembelajaran } \\
\text { Mind Mapping } \\
\text { Terhadap Hasil } \\
\text { Belajar Siswa } \\
\text { Kelas V Sekolah } \\
\text { Dasar Negeri } 2 \\
\text { Sumberrejo } \\
\text { Tahun Pelajaran } \\
\text { 2018/2019 }\end{array}$ & 2019 & $\begin{array}{l}\text { Berdasarkan hasil analisis data dan } \\
\text { pembahasan, maka kesimpulan yang } \\
\text { dapat diambil dari penelitian ini } \\
\text { adalah penerapan metode mind } \\
\text { mapping dapat meningkatkan hasil } \\
\text { belajar siswa. Peningkatan hasil } \\
\text { belajar dapat dibuktikan pada nilai } \\
\text { rata-rata hasil belajar siswa kelas } \\
\text { eksperimen } 86,65 \text { dengan persentase } \\
87 \% \text { dan nilai rata-rata hasil belajar } \\
\text { kelas kontrol } 77,48 \text { dengan } \\
\text { presentase } 77 \% \text {. }\end{array}$ \\
\hline 2. & Upik Elita & $\begin{array}{l}\text { Peningkatan } \\
\text { hasil beajar } \\
\text { menggunakan } \\
\text { metode } \\
\text { pembelajaran } \\
\text { Mind Mapping }\end{array}$ & 2018 & $\begin{array}{l}\text { Hasilnya menunjukkan peningkatan } \\
\text { setelah belajar menggunakan metode } \\
\text { mind mapping. Pra-tindakan } \\
\text { dilakukan untuk menentukan } \\
\text { persentase hasil belajar sebesar } \\
46,77 \% \text {, meningkat menjadi } 70,39 \% \\
\text { setelah siklus Pertama, dan } \\
\text { meningkat menjadi } 82.22 \% \text { setelah } \\
\text { siklus kedua. Simpulan. terjadi } \\
\text { peningkatan hasil belajar biologi } \\
\text { dengan menerapkan metode mind } \\
\text { mapping. }\end{array}$ \\
\hline 3. & $\begin{array}{l}\text { Nina Gantina } \\
\text { Kustian }\end{array}$ & $\begin{array}{l}\text { Penggunaan } \\
\text { metode Mind } \\
\text { Mapping untuk } \\
\text { meningkatkan } \\
\text { pembelajaran } \\
\text { IPS pada siswa } \\
\text { kelas VIII B } \\
\text { semester } 2 \\
\text { SMPN 1 } \\
\text { Bojonggenteng } \\
\text { Tahun Pelajaran } \\
\text { 2017/2018 }\end{array}$ & 2018 & $\begin{array}{l}\text { Jika siswa diajak belajar IPS dengan } \\
\text { menggunakan metode Mind Mapping } \\
\text { maka kemampuan mengeluarkan } \\
\text { pendapat akan meningkat. }\end{array}$ \\
\hline 4. & $\begin{array}{l}\text { - Rizki Annisa, } \\
\text { - Bambang } \\
\text { Subali, } \\
\text { - Wawan }\end{array}$ & $\begin{array}{l}\text { Peningkatan } \\
\text { daya ingat hasil } \\
\text { beajar soswa } \\
\text { dengan Mind } \\
\end{array}$ & 2018 & $\begin{array}{l}\text { Hasil penelitian menunjukan bahwa: } \\
\text { 1) penggunaan metode mind } \\
\text { mapping dapat meningkatkan daya } \\
\text { ingat siswa kelas IX MTs Al }\end{array}$ \\
\hline
\end{tabular}




\begin{tabular}{|c|c|c|c|c|}
\hline & $\begin{array}{l}\text { Prasetyo } \\
\text { Heryanto }\end{array}$ & $\begin{array}{l}\text { Mapping method } \\
\text { pada materi } \\
\text { listrik dinamis }\end{array}$ & & $\begin{array}{l}\text { Futuhiyyah dari } 38 \% \text { menjadi } 68 \% \text {, } \\
\text { 2) penggunaan metode mind } \\
\text { mapping dapat meningkatkan hasil } \\
\text { belajar siswa kelas IX MTs Al } \\
\text { Futuhiyyah dengan siswa yang } \\
\text { Mencapai KKM dari } 36 \% \text { menjadi } \\
56 \% \\
\text { 3) penggunaan metode mind } \\
\text { mapping dapat memfokuskan } \\
\text { perhatian dalam proses belajar siswa } \\
\text { kelas IX MTs Al Futuhiyyah dengan } \\
\text { persentase siswa } 72 \% \text {. }\end{array}$ \\
\hline 5. & Devi Setyarini & $\begin{array}{l}\text { Metode } \\
\text { Pembeajaran } \\
\text { Mind Map untuk } \\
\text { meningkatkan } \\
\text { prestasi belajar } \\
\text { anak didik } \\
\text { sekoah Dasar } \\
\end{array}$ & 2018 & $\begin{array}{l}\text { Perolehan dari adanya penerapan } \\
\text { metode pembelajaran Mind Map } \\
\text { begitu efektif dan efisien, sehingga } \\
\text { mampu memberikan daya tarik dari } \\
\text { siswa untuk fokus dalam proses } \\
\text { pembelajaran yang sedang } \\
\text { berlangsung. }\end{array}$ \\
\hline 6. & Sri Susanti & $\begin{array}{l}\text { Metode mind } \\
\text { mapping untuk } \\
\text { meningkatkan } \\
\text { hasil belajar IPS } \\
\text { di Sekolah Dasar }\end{array}$ & 2016 & $\begin{array}{l}\text { Dengan menerapkan metode Mind } \\
\text { Mapping pada proses } \\
\text { pembelajarannya mengalami } \\
\text { peningkatan. Hal ini dapat terlihat } \\
\text { dari hasil belajar peserta didik dari } \\
\text { siklus I sampai siklus II mengaami } \\
\text { peningkatan. Pada siklus I peserta } \\
\text { didik yang mendapatkan nilai diatas } \\
\text { KKM hanya berjumlah } 13 \text { orang dari } \\
21 \text { orang, sedangkan pada siklus II } \\
\text { berjumlah } 20 \text { orang dari } 21 \text { orang. } \\
\text { Kelulusannya meningkat dari } \\
(61,90 \%) \text { menjadi }(95,23 \%) \text {. }\end{array}$ \\
\hline 7. & Rijal Darusman & $\begin{array}{l}\text { Penerapan } \\
\text { metode Mind } \\
\text { Mapping (Peta } \\
\text { pikiran) untuk } \\
\text { meningkatkan } \\
\text { kemampuan } \\
\text { berpikir kreatif } \\
\text { Matematika } \\
\text { siswa SMP }\end{array}$ & 2014 & $\begin{array}{l}\text { Pencapaian kemampuan berpikir } \\
\text { kreatif matematik siswa, yang } \\
\text { pembelajarannya menggunakan mind } \\
\text { mapping lebih baik daripada yang } \\
\text { cara konvensional. }\end{array}$ \\
\hline 8. & $\begin{array}{l}\text { - Wayan } \\
\text { Darmayoga, } \\
\text { - Wayan } \\
\text { Lasmawan, } \\
\text { - A.A.I.N. } \\
\text { Marhaeni }\end{array}$ & $\begin{array}{l}\text { Pengaruh } \\
\text { implementasi } \\
\text { metode Mind } \\
\text { Mapping } \\
\text { terhadap hasil } \\
\text { beajar IPS } \\
\text { ditinjau dari } \\
\text { minat siswa } \\
\text { kelas IV SD } \\
\text { Sathya Sai }\end{array}$ & 2013 & $\begin{array}{l}\text { model pembelajaran Mind Mapping } \\
\text { dapat meningkatkan hasil belajar IPS } \\
\text { siswa kelas IV SD Sathya Sai } \\
\text { Denpasar }\end{array}$ \\
\hline
\end{tabular}




\begin{tabular}{|c|c|c|c|c|}
\hline & & Denpasar & & \\
\hline 9. & $\begin{array}{l}\text { Muhammad } \\
\text { Chomsi } \\
\text { Imaduddin \& } \\
\text { Unggul } \\
\text { Haryanto Nur } \\
\text { Utomo }\end{array}$ & $\begin{array}{l}\text { Efektifitas } \\
\text { metode Mind } \\
\text { Mapping untuk } \\
\text { meningkatkan } \\
\text { prestasi belajar } \\
\text { fisika pada siswa } \\
\text { kelas VIII } \\
\text { Muhammad } 8 \\
\text { Yogyakarta }\end{array}$ & 2012 & $\begin{array}{l}\text { Simpulan dari penelitian ini adalah } \\
\text { metode mind mapping berpengaruh } \\
\text { positif terhadap peningkatan prestasi } \\
\text { belajar fisika dibandingkan dengan } \\
\text { metode konvensional, sehingga ada } \\
\text { perbedaan prestasi belajar fisika yang } \\
\text { signifikan antara kelompok } \\
\text { eksperimen dan kelompok kontrol, } \\
\text { prestasi belajar fisika kelompok } \\
\text { eksperimen lebih tinggi dibandingkan } \\
\text { kelompok kontrol. }\end{array}$ \\
\hline 10. & $\begin{array}{ll}\text { Dida } & \text { Dwi } \\
\text { Kurniawati } & \end{array}$ & $\begin{array}{l}\text { Pengaruh } \\
\text { metode Mind } \\
\text { Mapping dan } \\
\text { keaktifan belajar } \\
\text { siswa terhadap } \\
\text { prestasi belajar } \\
\text { IPS pada siswa } \\
\text { KelasVIII SMP } \\
\text { Muhammadiyah } \\
5 \text { Surakarta } \\
\text { tahun pelajaran } \\
\text { 2009/2010 }\end{array}$ & 2010 & $\begin{array}{l}\text { Apabila metode mind mapping } \\
\text { diterapkan dalam pembelajaran } \\
\text { dengan siswa mampu membuat peta } \\
\text { gagasan dan ide dalam materi IPS } \\
\text { dan siswa mengikuti pembelajaran } \\
\text { secara aktif dalam berpendapat dan } \\
\text { aktif bertanya didalam pembelajaran } \\
\text { IPS maka prestasi belajar IPS pada } \\
\text { siswa kelas } \text { VIII SMP } \\
\text { Muhammadiyah } 5 \text { Surakarta akan } \\
\text { meningkat. }\end{array}$ \\
\hline
\end{tabular}

Hasil Analisis Penelitian Terkait Metode Pembelajaran Mind Mapping untuk meningkatkan hasil belajar siswa

Dari hasil analisis data di atas dapat ditarik kesimpulan menurut:

1. Nita Mei Ekawati, dan Diana Kusumaningrum: penerapan metode mind mapping dapat meningkatkan hasil belajar siswa.

2. Devi Setyarini: penerapan metode pembelajaran Mind Map sangat efektif dan efisien, sehingga mampu memberikan daya tarik dari siswa untuk fokus dalam proses pembelajaran yang sedang berlangsung.

3. Nina Gantina Kustian: Jika siswa diajak belajar IPS dengan menggunakan metode Mind Mapping maka kemampuan mengeluarkan pendapat akan meningkat.

4. Rizki Annisa, Bambang Subali, dan Wawan Prasetyo Heryanto: penggunaan metode mind mapping dapat meningkatkan daya ingat siswa, meningkatkan hasil belajar siswa dan dapat memfokuskan perhatian dalam proses belajar siswa

5. Upik Elita: Hasilnya menunjukkan peningkatan setelah belajar menggunakan metode mind mapping.

6. Sri Susanti: Dengan menerapkan metode Mind Mapping pada proses pembelajaran peserta didik mengalami peningkatan hasil belajarnya.

7. Rijal Darusman: Pencapaian kemampuan berpikir kreatif matematik siswa, yang pembelajarannya menggunakan mind mapping lebih baik daripada yang cara konvensional.

8. Wayan Darmayoga, Wayan Lasmwan, A.A.I.N. Marhaeni: model pembelajaran Mind Mapping dapat meningkatkan hasil belajar IPS siswa kelas IV SD Sathya Sai Denpasar 
9. Muhammad Chomsi Imaduddin \& Unggul Haryanto Nur Utomo: metode mind mapping berpengaruh positif terhadap peningkatan prestasi belajar fisika dibandingkan dengan metode konvensional

10. Dida Dwi Kurniawati: Apabila metode mind mapping diterapkan dalam pembelajaran maka prestasi belajar IPS pada siswa kelas VIII SMP Muhammadiyah 5 Surakarta akan meningkat.

Dengan demikian berdasarkan hasil analisis data dan pembahasan, maka kesimpulan yang dapat diambil dari penelitian ini adalah penerapan metode mind mapping dapat meningkatkan hasil belajar siswa. Peningkatan hasil belajar dapat dibuktikan dari 10 literatur yang terurai di atas.

\section{KESIMPULAN}

Berdasarkan hasil analisis data dan pembahasan di atas, maka kesimpulan yang dapat diambil dari penelitian ini adalah penggunaan metode mind mapping dapat meningkatkan hasil belajar siswa. Peningkatan hasil belajar dapat dibuktikan dari literatur yang diteiti.

\section{DAFTAR PUSTAKA}

Annisa R, Dkk. (2018). Peningkatan daya ingat hasil beajar soswa dengan Mind Mapping method pada materi listrik dinamis. Jurnal Pendidikan. Universitas Negeri Semarang.

Agustina, V. (2013). Penerapan Mind Mapping dalam Pelajaran IPA Pada MateriDaur Air untuk Meningkatkan Kemampuan Kreatif Siswa. Skripsi. PGSD, Universitas Pendidikan Indonesia, Bandung: Tidak Diterbitkan.

Buzan, T. (2013). Buku Pintar Mind Map. Jakarta: Gramedia Pustaka Utama.

Chen, C dan Jeng-Fung H. (2014). The Effects ofTeaching with Graphics Organizers on the Thingking Organizers of Students. US-China Education Review. (4) 4,261-267.

Darmayoga W, Dkk. (2013). Pengaruh implementasi metode Mind Mapping terhadap hasil beajar IPS ditinjau dari minat siswa kelas IV SD Sathya Sai Denpasar. e jurnal Program Studi Pendidikan Dasar. Program Pascasarjana Universitas Pendidikan Ganesha

Darusman Rijal. 2014 Penerapan metode Mind Mapping (Peta pikiran) untuk meningkatkan kemampuan berpikir kreatif Matematika siswa SMP. Jurnal Ilmiah MTs Miftahul Hasna.

Dimyati dan Mudjiono. (2009). Belajar dan Pembelajaran. Jakarta : Rineka Cipta

Djamarah, Syaiful Bahri. (2002). Strategi Belajar Mengajar. Jakarta: Rineka Cipta.

Ekawati M.N \& Kusumanginrum D. (2019). Pengaruh Penerapan Metode Pembelajaran Mind Mapping Terhadap Hasil Belajar Siswa Kelas V Sekolah Dasar Negeri 2 Sumberrejo Tahun Pelajaran 2018/2019. Jurnal Pendidikan Dasar Sekolah Dasar Negeri 2 Sumberrejo.

Elita U. (2018). Peningkatan hasil beajar menggunakan metode pembelajaran Mind Mapping. Jurnal Pendidikan Sekolah Menengah Atas (SMA) Negeri 2 Dumai.

Hamalik, Oemar. (2008). Proses Belajar Mengajar. Jakarta: Sinar Grafika.

Immadudin C,M \& Utomo N,H,U. (2012). Efektifitas metode Mind Mapping untuk meningkatkan prestasi belajar fisika pada siswa kelas VIII Muhammad 8 Yogyakarta. Jurnal Pendidikan Fakultas Psikologi Universitas Ahmad Dahlan.

Kustina Gantina N. (2018). Penggunaan metode Mind Mapping untuk meningkatkan pembelajaran IPS pada siswa kelas VIII B semester 2 SMPN 1 Bojonggenteng Tahun Pelajaran 2017/2018. Jurnal Inovasi Pendidikan Menengah. Vol 1.1 tahun 2021.

Kurniawati Dwi D. (2010). Pengaruh metode Mind Mapping dan keaktifan belajar siswa terhadap prestasi belajar IPS pada siswa KelasVIII SMP Muhammadiyah 5 
Surakarta tahun pelajaran 2009/2010 Program Studi Pendidikan Ekonomi Akuntansi Universitas Muhammadiyah Surakarta.

Nana Syaodih. (2009). Metode Penelitian Pendidikan. PT. Remaja Rosdakarya : Bandung.

Olivia, F. (2013). 5-7 Menit Asyik Mind Maping Kreatif. Jakarta.:Elex Media Komputindo.

Putra, Y. P. (2008). Memori dan Pembelajaran Afektif. Bandung: Yrama Widya

Setriyani D. (2019). Metode Pembeajaran Mind Map untuk meningkatkan prestasi belajar anak didik. Jurnal Pendidikan Dasar Universitas Islam Sultan Agung. Vol. 6 No. 1

Sudarman. (2009). Peningkatan Pemahaman dan Daya Ingat Siswa Melalui Strategi Preview, Question, Read, Reflect, Recite, dan Review (PQ4R). Jurnal Pendidikan Inovatif. Jilid 4. Nomor 2: 67-72.

Susanti Sri. (2016). Metode mind mapping untuk meningkatkan hasil belajar IPS di Sekolah Dasar. Jurnal Pendidikan Dasar Fakultas Ilmu Pendidikan Universitas Pendidikan Indonesia, Bandung

Swadarma, D. (2013). Mind Maping dalam Kurikulum Pembelajaran. Jakarta : Elek Media Komputindo.

Warseno, Agus dan Ratih Kumorojati. (2011). Super Learning: Praktik Belajar Mengajar yang Serba Efektif dan Mencerdaskan. Jogjakarta: Diva

Windura, S. (2013). 1 St Mind Map Untuk Siswa,Guru Dan Orang Tua. Jakarta: Elex Media Komputindo. 